NBER WORKING PAPER SERIES

\title{
INSTITUTIONAL ADAPTABILITY AND ECONOMIC DEVELOPMENT: THE PROPERTY RIGHTS REVOLUTION IN BRITAIN, 1700 TO 1830
}

\author{
Gary Richardson \\ Dan Bogart \\ Working Paper 13757 \\ http://www.nber.org/papers/w13757
NATIONAL BUREAU OF ECONOMIC RESEARCH
1050 Massachusetts Avenue
Cambridge, MA 02138
January 2008

We thank Jean-Laurent Rosenthal, Stergios Skaperdas, Linda Cohen, John Wallis, Tim Leunig, Richard Sylla, Mauricio Drelichman, and Joel Mokyr for helpful comments on earlier drafts. We also thank seminar participants at the University of British Columbia, New York University, and Washington Area Economic History Seminar and conference participants at meetings of the Economic History Society, the All-UC Group in Economic History, and the International Economic History Association. We thank Francesca Labordo and Patricia Suzuki for research assistance. We thank the Parliamentary Archives for assistance and advice. We thank the University of California for financial support. The views expressed herein are those of the author(s) and do not necessarily reflect the views of the National Bureau of Economic Research.

NBER working papers are circulated for discussion and comment purposes. They have not been peerreviewed or been subject to the review by the NBER Board of Directors that accompanies official NBER publications.

(C) 2008 by Gary Richardson and Dan Bogart. All rights reserved. Short sections of text, not to exceed two paragraphs, may be quoted without explicit permission provided that full credit, including $\odot$ notice, is given to the source. 
Institutional Adaptability and Economic Development: The Property Rights Revolution in Britain, 1700 to 1830

Gary Richardson and Dan Bogart

NBER Working Paper No. 13757

January 2008

JEL No. H1,K0,K1,N0,N43,P1,P10,P14,P16,P20,P26,P48

\begin{abstract}
Adaptable property-rights institutions, we argue, foster economic development. The British example illustrates this point. Around 1700, Parliament established a forum where rights to land and resources could be reorganized. This venue enabled landholders and communities to take advantage of economic opportunities that could not be accommodated by the inflexible rights regime inherited from the past. In this essay, historical evidence, archival data, and statistical analysis demonstrate that Parliament increased the number of acts reorganizing property rights in response to increases in the public's demand for such acts. This evidence corroborates a cornerstone of our hypothesis.
\end{abstract}

Gary Richardson

Department of Economics

University of California, Irvine

Irvine, CA 92697-5100

and NBER

garyr@uci.edu

Dan Bogart

3151 Social Science Plaza

University of California

Irvine, CA 92697-5100

dbogart@uci.edu 
... laws and institutions must go hand in hand with the progress of the human mind. As that becomes more developed, more enlightened, as new discoveries are made, new truths discovered and manners and opinions change, with the change of circumstances, institutions must advance also to keep pace with the times. We might as well require a man to wear still the coat which fitted him when a boy as civilized society to remain ever under the regimen of their barbarous ancestors.

Thomas Jefferson ${ }^{1}$

\section{Introduction}

Economists view secure property rights as necessary for economic development (Acemoglu and Robinson 2005; La Porta et al. 2004). This observation initially arose from studies of the property-rights system in nineteenth-century Britain (Coase 1960, 1974). The British example, some scholars argue, proves that establishing secure property rights is not merely a prerequisite, but is in itself sufficient, to trigger modern economic growth (North 1981, North and Weingast 1989). This essay offers a new lesson regarding property rights and economic progress. Britain's economic ascent began after Parliament established institutions enabling property rights to adapt to changing economic conditions and enabling land and resources to be reallocated towards more productive uses. Adaptable property rights, in other words, contributed to Britain's economic development.

Britain's medieval property system possessed characteristics common to landholding systems in developing nations, past and present. Rights of families and ancestors received prominence over the rights of individuals and descendents. A complex spectrum of overlapping privileges (common, communal, clerical, feudal, familial, statutory, and royal) enforced by an array of courts (manorial, county, clerical, and royal) pertained to most plots of land. These

1 Thomas Jefferson's letter to Samuel Kercheval, July 12, 1816. This quote is inscribed on the south-eastern interior wall of the Jefferson Memorial in Washington, DC. 
venues lacked uniform records and a unified framework for determining ownership, transferring rights, and adjudicating disputes.

Britain's antiquated system posed problems for people trying to reallocate resources towards more productive uses, particularly opportunities arising from technologies unanticipated in the distant past. Holders of estates could neither mortgage, nor lease, nor sell much of the land under their control. Holders under many types of tenures could only transfer property to particular persons or members of a local community. Residents often had to keep land in traditional uses. Residents could neither utilize resources in new ways, nor improve infrastructure, nor repackage rights without reaching agreements with all other parties possessing interests in a parcel, and such agreements could not, in most cases, be enforced by law, but could, in many instances, be challenged through courts.

Britain's medieval property system also inhibited localities from providing public goods, particularly those extending beyond the bounds of traditional communities or those necessitated by the expansion of commerce and cities. Communities lacked mechanisms for raising revenues and powers of eminent domain. Communities struggled to overcome free-riding, which inhibited the provision of public goods, and hold-outs, who withheld resources needed for public projects unless paid exorbitant sums. Market transactions might have alleviated these inefficiencies, but in most cases, the necessary transfers could not be consummated and the requisite contracts could not be enforced because of the restrictive nature of the anachronistic rights regime, which valued tradition and stability above innovation and flexibility.

English society struggled to improve the landholding system. In the six centuries following the Norman Conquest, the nation reformed landholding laws repeatedly. But, the principal problems persisted until the end of the seventeenth century, when Parliament embraced 
novel ideas concerning property and began processing petitions from groups hoping to reorganize rights to land and resources. Parliament reviewed requests from individuals, families, and communities, and after considering the interests of all concerned and the general public, rewrote rules regarding the use and ownership of property. Parliament enshrined these accords in three types of acts: estate, statutory authority, and enclosure. Estate acts altered the rights of individuals and families; eliminated restrictions on the uses to which property could be put; authorized the sale, mortgage, and leasing of land; and facilitated the enforcement of contracts. Acts establishing statutory authorities created new organizations that built, operated, and maintained infrastructure and public services. Statutory authorities received new rights, such as the authority to collect tolls, levy taxes, issue debt, and purchase land. These rights superseded traditional rights, such as burgesses' right to travel throughout the realm free from tax and toll, enshrined for centuries in town charters and the Magna Carta. Enclosure acts disbanded collectively-managed common-field villages and assigned to individuals rights to particular pieces of property. Enclosure acts also shifted commonly-held agricultural land to new uses, such as the construction of housing and workshops near growing towns and cities. Acts of all three types embodied the public's desire to reorganize rights and to reallocate resources towards more productive uses.

This essay shows that individuals and groups - including aristocratic estate holders, yeomen holding by custom of the manor, tenants on small plots, urban landlords, rural villages, nascent corporations, and growing urban communities - approached Parliament and requested to reorganize rights when economic opportunities made it profitable to do so and that Parliament accommodated the public's demands. Parliament favored petitions that left all pertinent parties as well (or better) off than under previous arrangements; that engendered little or no opposition; 
and that enhanced productivity, improved infrastructure, or provided public services. Parliament, in other words, functioned as a forum for facilitating agreements among individuals that reorganized property rights in ways that enabled resources to be put to more productive uses. This forum enabled society to voluntarily and peacefully restructure traditional arrangements in response to arising opportunities. This politically-fostered flexibility of property rights was, we argue, a key institutional innovation in England in the century preceding industrialization.

A principal testable implication of our hypothesis concerns the relationship between economic conditions and the passage of estate, statutory authority, and enclosure acts. If our hypothesis is correct, then conditions that increased returns from reorganizing rights - for example, economic booms that increased returns to investing in infrastructure or low interest rates that decreased the costs of financing construction - should have encouraged people to propose larger numbers of acts. Conditions that lowered returns from reorganizing rights should have reduced the number of proposals. In turn, if our hypothesis is correct, Parliament should have responded to increases (or decreases) in the public's demand for acts by increasing (or decreasing) the number of acts that it passed.

This essay tests these implications with new data on the number of acts that reorganized property rights and new methods designed to exploit that information to the fullest possible extent. Our methods begin with simple assumptions about the way in which Parliament and the political process operated, or in other words, the processes through which people proposed and Parliament passed acts. These assumptions yield a simple, structural model of the Parliamentary process, which in turn, yields a series of reduced-form equations that can be estimated to identify whether Parliament responded to changes in the public's demand for estate, enclosure, and statutory-authority acts. Mathematical propositions link the reduced-form and structural 
equations, illuminating the logical way to interpret our estimates. These methods enable us to account for econometric issues - such as the non-stationarity and heterogeneity of the statistical series - that complicate the process of drawing inferences from the data. These methods also enable us to eliminate plausible alternative explanations for the patterns apparent in the evidence, and thus, to draw causal conclusions from the correlations in the data.

The rest of this essay carries out this endeavor. The second section reviews the literature that sets the stage for our analysis. The third section describes the archival data that we employ and the new times series that we analyze. The fourth section introduces our mathematical model and statistical methods. The fifth section describes our empirical results. The concluding section discusses how Britain's gradual, consensual, and voluntary adoption of modern property rights facilitated economic expansion in the century preceding the Industrial Revolution and whether adaptable property-rights institutions can foster development in the world today.

\section{1: Literature Review}

Scholars have long studied the connection between politics, property rights, and prosperity in early-modern Britain. In The Wealth of Nations, for example, Adam Smith writes that "commerce could not flourish if people do not feel themselves secure in the possession of their property." ${ }^{2}$ Douglas North and Barry Weingast (1989) emphasize the role of the Glorious Revolution of 1688 , which they argue, created a constitutional consensus that prevented royal governments from expropriating citizens' property. Security of property rights encouraged investment and innovation, initiating Britain's industrial expansion.

Historians debate the accuracy of North and Weingast's interpretation of the Glorious Revolution. Critics include Gregory Clark and Patrick O’Brien. Clark (1996) argues that secure

2 Smith 1976, p. 910 
property rights existed far into the English past. Expropriation occurred only in exceptional circumstances, such as when individuals rebelled against the regime. O'Brien (1994) argues that the Glorious Revolution weakened property rights. After the Glorious Revolution, Parliament raised taxes, embarked on foreign wars, and regulated a wide-array of industries. Alternative interpretations of Parliament's impact on the economy abound. Paul Langford (1991) stresses Parliament's active involvement in local legislation and argues that after 1688 propertied Englishman used their control of the political system to enact changes in property rights arrangements which benefited themselves as well as the larger economy. Julian Hoppit (1996, 1997) finds that the success rate for personal, communications, and enclosure acts increased significantly in the early eighteenth century, and argues that Parliament had a capacity to meet private or local demands for legislation. Hoppit's work documents the rapid expansion of Parliamentary activity after the Glorious Revolution and builds upon a venerable tradition of categorizing and counting acts. Examples include Tate (1967 and 1978), Turner (1980 and 1984), Innes (1997), and Wordie (1983).

We build upon this foundation by counting annual numbers of acts that altered property rights between 1700 and 1830 . We compare this count to economic and political variables that influenced the benefits and costs of reorganizing rights to land. The spirit of this exercise resembles the work of N.F.R. Crafts (1977) and Clark (2001). Both authors discuss the correlation between the number of enclosure acts, wheat prices, and interest rates.

This essay extends that line of reasoning in several ways. First, it examines all types of acts that altered property rights arrangements, rather than one type among many. Second, this essay deals with crucial issues of statistical inference and identification. Its statistical methods ensure that correlations between property rights and economic incentives arise for real reasons, 
rather than statistical phenomena that frequently generate spurious correlations between timeseries variables that trend across time. Third, this essay derives its statistical tests from straightforward economic models that reveal how to appropriately interpret the estimates. Fourth, this essay examines both treatment and control groups. The control groups consist of acts that were processed using the same procedures as estate, enclosure, and statutory authority acts and that performed tasks similar to those acts, but which did not alter property rights. Overall, this essay's statistical methods yield robust conclusions about the nature, causes, and consequences of Parliament's behavior.

This essay extends the law and economics literature by emphasizing the importance of adaptable property-rights institutions. Previous scholars emphasized the security of rights, which historians believe existed long before the seventeenth century. We emphasize features of the English political and legal system that arose after the Glorious Revolution at the end of the seventeenth century. These novel features enabled Parliament to reform property rights on a voluntary, gradual, and piecemeal basis. The Parliamentary forum that undertook this task possessed no historical precedent.

\section{Acts that Reorganized Rights to Land and Resources}

This section describes estate, statutory authority, and enclosures acts, which comprised over half of all legislation passed between 1688 and 1830. These acts possessed common themes. All affected individuals' and organizations' rights. Some created new rights. Others altered or annulled old rights. Some created new organizations, such as turnpike trusts. Others disbanded existing organizations, including ancient entities, such as village councils and manorial courts.

\subsection{Estates acts}


Estate acts enabled holders of property to take some action prohibited by the rules under which they had inherited their land. Estate acts were necessary because the inheritance system limited estate holder's power over their property, largely in an effort to adhere to the wishes of the deceased (who bequeathed the property to their descendents as long as the latter fulfilled conditions set out in the settlement), to protect the interests of dependents and heirs, and to preserve a family's estate for future generations (English and Saville, 1983, pp. 19-21). This system of inheritance, known as strict settlement, solidified during the seventeenth century and prevailed until the nineteenth century. A settlement was a generic name for a property transaction and for the documents created in its consummation. While estimates vary, at the peak, at least one-quarter and as much as three-fourths of land in England was held through strict settlements (English and Saville, 1983, pp. 11-12, 30; Habakkuk 1994).

Three features of settlements generated a need for Parliamentary involvement. First, without an act of Parliament, holders of settled estates could only change the terms of the settlement when their heir came of age (i.e. reached the age of 21). Then, the holder and heir (typically father and son) could join forces and amend the settlement via the process of common recovery. Limited life spans meant that settlements could be changed only infrequently. A family might wait decades (or generations) for an heir to come of age and for the holder and heir to reach an agreement about restructuring the estate.

Second, settlements restricted the uses to which land could be put. The reason for these restrictions was protecting the rights of dependents and future heirs. Holders of a settled estate (who were just life tenants) could grant neither leases lasting beyond their lives nor leases from which they benefited at the expense of their heirs (such as leases in which tenants paid lump sums up front in return for concessions). Holders could seldom sell, swap, or mortgage property 
under their control. Holders could not alter property, even if they considered the alterations to be an improvement, without risking legal suits. The removal of trees, hedges, and buildings; the mining of minerals, quarries, and peat bogs; and the conversion of arable lands into pasture (or vice versa) could be considered waste, since these actions converted permanent resources into current income. All those who benefited from such actions could be liable for damages if dependents or heirs claimed to be harmed. Courts allowed sales, exchanges, mortgages, improvements, and long-term leases only if the settlement contained specific clauses authorizing such actions. Settlements written in the seventeenth and early eighteenth centuries seldom provided such powers, although as the eighteenth century progressed and as the law concerning settlements became increasingly sophisticated, settlements tended to provide broader powers.

Three, conducting transactions and enforcing contracts on settled land could be costly, uncertain, and insecure. Settlements were long, complex documents, often unpunctuated and repetitious. ${ }^{3}$ Interpreting settlements required experience, skill, detailed knowledge of the document, and a large library of property laws, precedents, and legal texts estimated at 674 volumes in 1826 (English and Saville, 1983, p. 18). Settlements were not part of the public record. Copies of the deeds were usually held by the settlers, trustees, and lawyers. Settlements had to be consulted before taking out mortgages, drawing up leases, or completing sales, because if the settlement did not specifically authorize a transaction, the transaction could be voided. Ambiguities in settlements often deterred individuals from acting for fear that the transactions would be disputed.

Estate acts solved these problems. Estate acts facilitated the enforcement of contracts by clarifying permissible transactions and the rights of pertinent parties. Estate acts authorized

3 The fact that until the Conveyancing Act of 1881, solicitors were paid for conveyances by the word (1s for every 72 words in 1862), did not encourage conciseness (England and Seville, 1983, p. 18). 
actions previously prohibited by settlements such as the mortgaging of property, cutting of oldgrowth timber, and mining of ores and minerals. Estate acts authorized the sale and leasing of land. The authorization of sales and leases may have been one of the most significant effects of estate acts, since large tracts of English land became exposed to competitive pressures provided by the marketplace, and began to be used in a more productive manner.

\subsection{Statutory Authority Acts}

Statutory authority acts fostered the construction, improvement, and maintenance of infrastructure and social services. Statutory acts focused on particular topics. Transportation acts promoted roads, bridges, river navigation, ports, canals, and railways. Urban improvement acts provided for street paving, gas lighting, garbage collection, sewage extraction, water provision, and police protection. Government building acts fostered the construction of prisons, courthouses, and county administrative offices. Poor relief acts provided assistance for the poor and encouraged the construction of workhouses. Court of small request acts established legal forums for adjudicating credit contracts valued at less than 40 shillings. Lighthouse acts authorized whomever built lighthouses on particular plots of land to collect tolls from all ships that passed.

To accomplish these tasks, statutory authority acts created non-profit organizations and enjoined the trustees of these entities to serve the public interest. ${ }^{4}$ The trustees tended to be local landowners and merchants, who served without remuneration. For canals and railways, however, statutory authority acts established for-profit organizations such as joint-stock companies, whose directors purchased shares of the organizations and profited from their investments.

4 See Webb and Webb (1963) for a description of the organizations established by statutory authority acts. 
Statutory authority acts granted rights to these new organizations. One was the right to levy user-fees and/or raise revenue through other means. A turnpike act, for example, authorized a trust operating a turnpike to levy tolls on road-users and claim labor (or the equivalent in taxes) from inhabitants along the road. The tolls marked a significant departure from the existing system, in which parishes paid for road improvements with local labor and property taxes, and in which individuals possessed the right of free passage, enshrined in medieval town charters and confirmed by the Magna Carta. Trustees also received the right to issue debt and equity. The bonds were secured by the tolls. If interest payments fell into arrears, bondholders could seize the toll revenues.

Statutory authority acts gave organizations the right to purchase land along a route's right of way and defined procedures for doing so. The act authorized the organization to negotiate with landowners. If the parties could not agree on the price for a necessary plot of land, the organization could appeal to a body of commissioners who could compel the landowners to sell. These procedures provided the legal origin for modern laws concerning eminent domain.

Statutory authority acts limited the powers of trustees. Turnpike acts, for example, defined maximum tolls. In each act, a schedule distinguished different types of traffic and goods, and for each group, a maximum permissible toll. Similar schedules regulated the issuance of debt and terms of interest.

Statutory authority acts could be amended by subsequent acts which clarified the rights and responsibilities of the organization. Canal acts were often amended in order to add branch lines or to increase the authorized capital. Turnpike acts had to be renewed, since they expired after 21 years. Renewals often expanded trustees' authority, by allowing them to manage a larger road network or altering the schedule of tolls. 


\subsection{Enclosure Acts}

Enclosure acts reorganized rights to property, usually in open-field agricultural villages. At the beginning of the eighteenth century, approximately one-quarter of the arable land in England lay in such villages, where residents shared rights to communal assets, such as water, pasture, and woods. Villagers also shared rights in the large open fields, which served as common pasture during fallow periods and as cropland during the growing season. The cropland was divided among the residents, who possessed the right to grow grain on acre-sized plots scattered throughout the fields and intermingled with those of their neighbors. Villagers managed these collective assets, such as the open arable fields, through village institutions, including customary laws and manorial courts.

Enclosure acts replaced collective ownership of common resources with individual ownership of particular plots of land, and replaced collective management through village institutions by individual management of personal estates. An enclosure act appointed a commission to implement the terms of the act. ${ }^{5}$ The commission employed surveyors to draw a map of the village with its open fields and strips, tofts and crofts, waste and pasture, and other physical features. The surveyors recorded the holders of rights to all of these assets. At a series of public meetings, holders of land (and all other rights in the village) advanced claims as to what they should receive under the new arrangements. The commissioners decided on the validity of these claims. After they made their decisions, the surveyors created a map of the new village, displaying the new features, such as fields, roads, fences, and irrigation channels, and the owners of each.

\footnotetext{
In 1801, the first General Enclosure Act simplified the administration of enclosure bills by providing guidelines
} for those drafting enclosure bills and parameters for permissible outcomes. 


\subsection{The Process of Passing Acts}

In the 1690 s and early 1700 s, Parliament standardized procedures for processing estate, statutory authority, and enclosure bills. Estate acts began with a petition from an individual or family desiring to change the rules regarding their estate. The petitioner hired a lawyer specializing in estate law to prepare their paperwork. A Parliamentary committee investigated the merits of the petition and issued a report. Petitions deemed beneficial to all interested parties were written into bills, read to the public three times, passed through both Houses of Parliament, and then sent to the King for royal assent. Public notice ensured that individuals with interests in the estate knew about the proposal. Parties could oppose the bill by submitting counter-petitions to either house of Parliament. Parliamentary committees considered the contending proposals, and then passed one of the bills, modified the original bill to satisfy the opposition, or rejected both proposals. The multiple layers for review and numerous opportunities for opposition ensured that Parliament considered the interests of all concerned before coming to a decision (English and Saville, 1983, p. 50).

Statutory authority acts began with a petition from a community stating a problem, such as insufficient road capacity between two places, and proposing a solution, such as the creation of a turnpike between the cities. A Parliamentary committee considered the petition and drafted a bill on this issue. The bill was read publicly three times before both houses of Parliament. The readings allowed potential opponents to express opinions and propose amendments. Advocates and opponents typically hired solicitors to present their cases and promote their interests. Like modern-day lobbyists, these solicitors maintained regular contact with members of the committees working on these issues. 
Enclosure acts went through a similar procedure. Parities interested in an enclosure held a series of public meetings in their village to discuss the issue, and then drafted a petition signed by a sufficient group (typically four-fifths) of individuals possessing rights to the land under consideration. Advocates submitted the petition to Parliament, where the bill was read publicly three times and considered by both houses.

Parliament employed similar procedures for many types of acts that did not alter property rights arrangements. The procedures for estate acts, for example, were identical to the procedures for private acts of all types, including divorces, marriages, naturalizations, and appointments to official positions that provided salaries or pensions.

\section{Data}

The Parliamentary Archive is the principal repository for historical information on acts of Parliament. The Archive maintains a computerized catalogue, Portcullis, which indicates the clerical title, calendar year, regal year, and parliamentary session for all acts passed since the sixteenth century. ${ }^{6}$ Clerks inscribed clerical titles on the exterior of a roll of parchment containing the full text of an act when Parliament reviewed the original legislation. The clerical title summarized the act, usually in a concise paragraph containing enough information for the clerks to identify the act and its principal provisions amidst thousands of similar pieces of parchment, without opening the rolls to read the full text.

An earlier paper explains our process for converting the clerical title of every act of Parliament into a vector of variables (Bogart and Richardson, 2007). In this essay, we convert those vectors of variables into time series suitable for statistical analysis. Tables 1 through 3

${ }^{6}$ http://www.portcullis.parliament.uk. The clerical titles within Portcullis were first published in two nineteenth century compilations of Parliamentary legislation, Statutes of the Realm (Great Britain, 1800) and Statutes at Large (Great Britain, 1807), which were computerized during the 1990s. 
describe those series. The top-half of Table 1 describes estate acts. Row (a) refers to the series indicating the total number of estate acts passed each year. Column (1) indicates that ALL of these acts altered property rights. Column (2) indicates that SOME of these acts also altered personal rights. Columns (3) through (6) describe the statistical properties of the series. We refer to this as the series in "levels", since it is based on the raw series indicating the annual number (or level) of acts passed. Column (3) indicates the annual average. Column (4) indicates the standard deviation. Column (5) indicates the minimum number passed in a single year. Column (6) indicates the maximum number. Columns (7) through (10) present the same information for the series in differences (i.e. the change in the number of acts passed from year $t-1$ to year $t$ ). Row (b) describes a time series indicating the annual number of estate acts that authorized the sale of property. Row (c) indicates the annual number of estate acts that authorized the leasing of property. Row (d) indicates the annual number of acts that authorized either sales or leases. Our analysis emphasizes estate acts authorizing sales and leases because these acts placed land long bound by the fetters of the past onto the market, which was (and is) one of the most efficient methods for reallocating resources.

The bottom-half of Table 1 describes data that serve as a comparison (or control) group for estate acts. These non-estate private acts dealt with issues of marriage, naturalization, and appointments to office. These appear in rows (e) through $(\mathrm{g})$ respectively. The sum of these series appears in row (h). Marriage acts permitted individuals to marry and/or divorce in contravention of secular and religious statutes. Naturalization acts provided foreign-born denizens with the rights of native-born citizens. Office acts appointed individuals to positions in the royal household, courts of law, executive agencies, and other positions that provided government-funded livings. Important similarities existed between these marriage, 
naturalization, and office acts (collectively called non-estate private acts) and the estate acts examined in the top of the table. When processing all of these acts, Parliament followed common procedures. Similarities also existed in the clientele that requested these acts, the demographic and social forces that generated demand for these acts, and the political factors that influenced the supply of these acts. A key feature, however, distinguishes estate and non-estate private acts. The value of estate acts varied with economic conditions that influenced the costs and benefits of reorganizing rights to land. The value of marriage, naturalization, and office acts did not.

The top-half of Table 2 describes statutory authority acts. Row (a) indicates the annual number of statutory authority acts passed each year. Row (b) indicates the annual number of acts pertaining to transportation, principally roads, canals, harbors, rivers, bridges, and railways. Row (c) indicates the annual number of acts pertaining to urban improvements, principally the provision of water, sewers, market infrastructure, public buildings, gas lighting, garbage collection, church maintenance, courts of small request, poor relief, prison construction, and police protection. Column (1) indicates whether these acts reorganized rights to land and resources. Column (2) indicates whether these acts facilitated or financed the improvement of infrastructure (I) or the provision of public services (S). The definitions of the columns (3) through (6) and (8) through (11) are identical to the definitions of the corresponding columns in Table 1. Columns (7) and (12) indicate whether the series are stationary, as determined by an Augmented Dickey-Fuller Test. While several series are non-stationary in levels, all of the series are stationary in differences.

The bottom-portion of Table 2 describes data that serve as a comparison (or control) group for statutory authority acts. We refer to the control group as finance acts. These acts dealt with national government expenditure and taxation. Most pertained to excise, customs, and land 
taxes; the development of economic and military infrastructure; and the provisioning of military forces. Like statutory authorities, these acts financed the provision of public goods, and their passage through Parliament required balancing local and broader interests. Unlike statutory authority acts, however, demand for these acts depended largely on the dictates of foreign affairs, and little on the costs and benefits of reorganizing rights.

Table 3 describes enclosure acts. The last row of the table describes a useful control group, amendments to enclosure acts. Amendments serve as an illuminating comparison because their passage followed procedures identical to initial enclosure acts, but demand for amendments arose primarily after random instances when errors crept into original legislation during the long process of passing Parliament.

The accuracy of the data depicted in Tables 1 through 3 depend upon our ability to accurately determine the date on which acts passed. For most of our sample period, a convention dated all acts passed by a session of Parliament as if they passed on the opening day of the session. This convention lingered from an earlier period when Parliament met infrequently at royal request and handled a limited volume of business in a short time period. In the eighteenth century, Parliament met annually. Sessions began in the fall, usually in the months of October, November, or December; lasted throughout the winter; and adjourned in the spring. Complications arose, however, in the winters of 1714-1715, 1751-1752, and 1760-1761, when the monarch died, and/or Parliament opened late. In 1714, for example, Queen Anne died. George I assumed the throne. His ascension delayed the opening of Parliament until January of 1715. This parliament adjourned in the spring and another opened on schedule during the next fall. So, in the year 1715, the conventional dating method assigned the acts passed in two Parliamentary sessions - the winters $1714-15$ and $1715-16$ - to one calendar year, 1715 . We 
correct for this confusion in two ways. First, we run regressions with the raw data, while assigning dummy variables to the years in which Parliament did not meet and the years in which Parliament met twice. Second, we drop the period of problematic dating from our sample, and run regressions for the years 1763 through 1830, when all acts are precisely dated. The two methods yield similar results.

Table 4 lists the explanatory variables. Rows (a) and (b) refer to two variables, the real interest rate and the volume of foreign trade, which influenced the demand for estate, enclosure, and statutory authority acts. The real interest rate determined the cost of investment and rate of intertemporal exchange, which were principal factors determining the returns from reorganizing property rights. $^{7}$ The volume of foreign trade was a good measure of aggregate economic activity, which was a principal determinant of revenues earned by improving infrastructure and reallocating resources towards new and more productive uses. The volume of trade also measured the health of the industrial and mercantile sectors relative to the agricultural economy. ${ }^{8}$

Rows (c), (d), and (e) refer to variables that influenced the number of days that Parliament sat in session and legislators' incentives for passing large volumes of local legislation. Together, these variables - years when the monarch died, years when a new prime minister assumed office, and years when Parliamentary elections occurred - were principal factors propelling annual variation in Parliamentary productivity. ${ }^{9}$ Additional explanatory variables, listed in Rows (f) through (k), include indicators for years when Britain was at war, when Britain suffered disease epidemics, and when Britain changed the structure of its land tax

7 Our real interest rate is the nominal interest rate, measured as the yield on long-term government bonds, known as $2 \frac{1}{2} \%$ consols from Neal (1990), minus inflation, measured as a three-year moving average of the percentage change in Clark's (2001) consumer price index.

8 Our measure of the volume of foreign trade, like most scholars, is the sum of the official value of imports plus exports (Mitchell, 1988). The official values reflect changes in the quantity of imports and exports weighted by a particular set of prices fixed at the outset of the eighteenth century.

9 We take these variables from histories of England and its government by Holmes (1993), Holmes and Szechi (1993), and Evans (2001). 
system. The set of explanatory variables also includes (g) the land tax rate in shillings per acre, (h) an index of climatic conditions, based on tree ring measurements, which reflects exogenous factors effecting agricultural productivity. Year-to-year changes in these variables were driven principally by natural phenomena, such as weather and mortality, and international events, such as relations with colonies and foreign rebellions. Thus, year-to-year changes in these variables were largely exogenous to the British economy.

\section{Methods}

This section establishes a framework for analyzing data described in the preceding section. The goal is to derive straightforward statistical tests that yield robust results with broad implications. The analysis begins with intuition standard among social scientists. Private parties desired Parliament to pass acts. Their desires fluctuated as the value of acts fluctuated. Economic conditions which altered the costs and benefits of acts propagated those fluctuations. Economists summarize such relationships with an inverse demand function.

(1) $p_{d}=F\left(q_{d}, X\right)$

In this equation, $p_{d}$ indicates the maximum amount that the public would expend to secure the passage of a certain quantity of legislation, $q_{d} . X$ indicates the array of economic factors that influenced the costs and benefits of legislation. $X=\left\{x_{1}, x_{2}, \ldots, x_{I}\right\}$, where $x_{i}$ represents the $\mathrm{i}^{\text {th }}$ factor. To keep the notation clear, assume $0<\partial F / \partial x_{i}<\infty \quad \forall i=1, \ldots, I$. Since F represents demand, $\partial F / \partial q<0$.

The number of acts depended upon the time, effort, and resources that the legislature and bureaucracy expended in the approval process as well as factors that influenced legislative productivity, such as elections, changes in governments, monarchial mortality, and the need to devote time to alternative matters, such as discussing military and international affairs. The 
number of acts passed also depended upon the lawyers, lobbyists, and peripheral personnel that supplicants employed to prepare and advance their petitions as well as the procedures, payoffs, and side payments - both in London and the local community - that lubricated lawmaking in London. We summarize this complex process with a supply function.

$$
p_{s}=G\left(q_{s}, Z\right)
$$

$p_{s}$ indicates the costs of passing a quantity of legislation, $q_{s}$. $\mathrm{Z}$ indicates the array of factors influencing the supply of legislation. Symbolically, $Z=\left\{z_{1}, z_{2}, \ldots, z_{J}\right\}$, where $\mathrm{z}_{i}$ represents the $\mathrm{j}^{\text {th }}$ factor. To keep the notation clear, assume $\partial G / \partial z_{j}>0 \quad \forall j=1, \ldots, J$. In the short run, increasing the quantity of acts required more intensive employment of factors with diminishing returns and rising costs. So, $\partial G / \partial q \geq 0$.

The interaction of supply and demand determines the quantity of acts that Parliament passes. This equilibrium occurs when the demand price, $p_{d}$, equals the supply price, $p_{s}$, plus some markup, $m$.

$$
\text { (3) } \quad p_{d}=p_{s}+m
$$

If the markup exceeds zero, then someone in the act-passing process (either lobbyists, opponents of the legislation, or members of Parliament) were able to extract some of the surplus generated by the legislation, and the equilibrium occurs at the intersection of the supply and marginal revenue curves. If the markup equals zero, then the act-passing process was completely competitive, and the equilibrium occurs at the intersection of the demand and supply curves. Substituting Equations (1) and (2) into Equation (3) reveals the number of acts passed in equilibrium.

$$
\text { (4) } \quad F\left(q^{*}, X^{*}\right)-G\left(q^{*}, Z^{*}\right)=m
$$


Here, the asterisk superscript indicates quantities of variables in equilibrium. Rewriting the equilibrium condition emphasizes the implicit relationship between the equilibrium values of the variables.

$$
H\left(q^{*}, X^{*}, Z^{*}\right) \equiv F\left(q^{*}, X^{*}\right)-G\left(q^{*}, Z^{*}\right)=m
$$

The implicit function theorem describes the relationship between the function, $H$, the equilibrium level of quantity demanded, $q^{*}$, and the variables that shift supply and demand, $X$ and $Z$.

(6") $\quad \frac{\partial q^{*}}{\partial z_{i}}=(-1) \frac{\partial H\left(q^{*}, X^{*}, Z^{*}\right) / \partial z_{i}}{\partial H\left(q^{*}, X^{*}, Z^{*}\right) / \partial q^{*}}=\frac{-\partial G\left(q^{*}, Z^{*}\right) / \partial z_{i}}{\partial F\left(q^{*}, X^{*}\right) / \partial q^{*}-\partial G\left(q^{*}, Z^{*}\right) / \partial q^{*}}$

The total differential of (6) provides a linear approximation of the relationship in the neighborhood of the equilibrium.

$$
D q^{*}=D Q\left(X^{*}, Z^{*}\right)=\sum_{i=1}^{I} \frac{\partial q^{*}}{\partial x_{i}} d x_{i}+\sum_{j=1}^{J} \frac{\partial q^{*}}{\partial z_{j}} d z_{j}
$$

This relationship can be estimated with the data described in the preceding section. The change in the quantity of acts, $D q^{*}$, is the change in the number of acts passed from year $t-1$ to year $t$. The changes in the independent variables, $d x_{i}$ and $d z_{j}$, are changes in variables that influence demand and supply from year to year. The estimating equation is

$$
\Delta A_{t}=\sum_{i=1}^{I} \alpha_{i} \Delta x_{i, t-1}+\sum_{j=1}^{J} \beta_{j} \Delta z_{j, t-1}+\varepsilon_{t}
$$

where $\Delta A_{t}$ is the change in the number of acts from $t-1$ to $t . \Delta x_{i, t-1}$ is the change in the $\mathrm{i}^{\text {th }}$ demand shift variable from $t-2$ to $t-1 . \alpha_{i}$ is an estimate of $\partial q_{*} / \partial x_{i} \cdot \Delta z_{j, t-1}$ is the change in the $\mathrm{j}^{\text {th }}$ supply shift variable from $t-2$ to $t-1 . \beta_{j}$ is an estimate of $\partial q_{*} / \partial z_{j}, \varepsilon_{\mathrm{t}}$ is an error term. 
While the series, $A_{t}, x_{i, t-1}$, and $z_{j, t-1}$, exhibit trends and are non-stationary, the differences of those series, $\Delta A_{t} \Delta x_{i, t-1} \Delta z_{j, t-1}$, which enter the estimating equation, are stationary. The error term, $\varepsilon_{\mathrm{t}}$, is auto correlated and heteroskedastic. Because of these characteristics of the residual, the Newey-West procedure for estimating a heteroskedastic and autocorrelation consistent covariance matrix is the appropriate method for calculating the standard errors of our estimates. ${ }^{10}$

Our estimates of $\partial q^{*} / \partial x_{i}$ and $\partial q^{*} / \partial z_{j}$ do not allow us to recover the parameters of the underlying supply and demand curves, $F$ and $G$. However, our estimates do enable us to characterize the shapes of those curves. Propositions 1 and 2 indicate how.

Proposition 1. If $\partial q_{*} / \partial x_{i} \neq 0$ for some $i$, then $\partial G\left(q_{*}, Z_{*}\right) / \partial q_{*}<\infty$.

Proof. This is a proof by contraposition. Assume $\partial G\left(q_{*}, Z_{*}\right) / \partial q_{*}=\infty$. Then,

$$
\begin{aligned}
& \frac{\partial q_{*}}{\partial x_{i}}=\frac{-\partial F\left(q_{*}, X_{*}\right) / \partial x_{i}}{\partial F\left(q_{*}, X_{*}\right) / \partial q_{*}-\infty}=0 \quad \forall i=1, \ldots, I \text { because } \partial F\left(q_{*}, X_{*}\right) / \partial q<0 \text { and } \\
& \partial F\left(q_{*}, X_{*}\right) / \partial x_{i}<\infty
\end{aligned}
$$

In prose, Proposition 1 indicates that if the quantity of acts fluctuated in response to fluctuations of one (or more) of the factors that influenced the demand for acts, then the supply curve for acts was not perfectly inelastic.

Proposition 2. If $\partial q_{*} / \partial z_{j} \neq 0$ for some $j$, then $\partial F\left(q_{*}, X_{*}\right) / \partial q_{*}>-\infty$.

Proof. This is a proof by contraposition. Assume $\partial F\left(q_{*}, X_{*}\right) / \partial q_{*}=-\infty$. Then, $\frac{\partial q_{*}}{\partial z_{j}}=\frac{-\partial G\left(q_{*}, Z_{*}\right) / \partial z_{j}}{-\infty-\partial G\left(q_{*}, Z_{*}\right) / \partial q_{*}}=0 \quad \forall j=1, \ldots, J$ because by definition $\partial G\left(q_{*}, Z_{*}\right) / \partial q_{*} \geq$ 0 and $\partial G\left(q_{*}, Z_{*}\right) / \partial z_{j}<\infty$.

10 Whitney K. Newey; Kenneth D. West. “A Simple, Positive Semi-Definite, Heteroskedasticity and Autocorrelation Consistent Covariance Matrix." Econometrica, Vol. 55, No. 3. (May, 1987), pp. 703-708. 
In prose, Proposition 2 states that if the quantity of acts fluctuated in response to fluctuations of one (or more) of the factors that influenced the supply for acts, then the demand curve for acts was not perfectly inelastic.

Determining whether $\alpha_{i}$, our estimate of $\partial q_{*} / \partial x_{i}$, and $\beta_{j}$, our estimate of $\partial q_{*} / \partial z_{j}$, differ from zero involves hypothesis tests. For the null hypothesis $\alpha_{i}=0$, the alterative hypothesis is $\alpha_{i}$ $\neq 0$. For the null hypothesis $\beta_{j}=0$, the alterative hypothesis is $\beta_{j} \neq 0$. The test statistic has a tdistribution.

In addition to being straightforward, our tests have desirable properties. They are consistent with almost any plausible structure for the system that produced Parliamentary acts. They assume little about the data generating process and remain robust to a wide range of statistical complications. They use the data at hand to answer the questions that we posed. Did increases in the benefits of reorganizing property rights induce the passage of more estate, enclosure, and statutory authority acts? Did Britain's Parliament accommodate the public's demand to reorganize property-rights and reallocate resources towards more productive uses?

\section{Results}

Table 5 presents results of this exercise for estate acts. Column (1) regresses the year-toyear change in the annual number of estate acts on year-to-year changes in variables that influence the demand for acts: the real interest rate and the volume of trade. The regression spans the 124 years for which we have data suitable for statistical analysis. The initial year, 1705, lies close to the point where Parliament formalized procedures for processing acts regarding property rights. The final year, 1830, lies close to the nationwide reform of Parliamentary elections and procedures enshrined in the Great Reform Act of 1832. The regression reveals a correlation between changes in the number of acts and changes in the real interest rate. When the interest 
rate rose and the cost of investing increased, the number of estate acts fell, as our hypothesis predicts. The correlation is significant in statistical terms and substantial in magnitude. Column (2) adds year-to-year changes in three explanatory variables that influenced the productivity of parliament: election years, changes of the prime minister, and the death of a monarch. In this specification, as in all others, the coefficient on the real interest rate remains statistically and economically significant. Column (3) adds additional explanatory variables, including the yearto-year changes in the real land tax rate, years where the tax code changed, tree ring growth, epidemic mortality, and war years. ${ }^{11}$

Columns (4) through (6) perform the same exercise for a control group: marriage, naturalization, and office acts. These non-estate private acts resembled estate acts in many dimensions - including typical clientele and procedures for passing parliament - but the value of acts in the control group did not depend upon returns from reorganizing property rights. Why do we need a control group? It is possible that the regressions in Columns (1) through (3) do not control for some unobserved factor correlated with both the real interest rate (our independent variable) and with the number of estate acts (our dependent variable). The exclusion of this unobserved variable might make it appear as if the real interest rate influenced the demand for estate acts, when in actuality, the excluded variable was the source of the correlation. Columns (4) through (6) address this issue by indicating whether correlations existed between the economic forces that influenced the passage of estate acts and non-estate private acts, for which the demand did not depend upon factors that influenced the returns from reorganizing property rights. If such correlations existed, then the coefficient on the real interest rate in columns (4)

11 An array of robustness checks that we report in earlier versions of this paper demonstrate that the regressions are robust to a wide range of alternative specifications. Neither the signs nor the significance levels of the coefficients change when the endpoints of the analysis change by up to two decades. The signs and significance levels are also invariant to the inclusion of additional explanatory variables such as year-to-year changes in the level of population, industrial production, Parliamentary majorities, and military conflicts. 
through (6) would be statistically and substantively significant. The coefficients are, however, insignificant, indicating that excluded variables that influenced private acts' passage through Parliament did not drive the results of specifications (1) through (3).

Columns (7) and (8) reinforce this result. Column (7) employs non-estate private acts as an explanatory variable. Column (8) employs the residual from a regression of all non-estate private acts on the explanatory variables in columns (4) through (6). The results of these regressions indicate that non-estate private acts were correlated neither with the real interest rate nor with acts that reorganized property rights. These results can be restated. In our analysis, interest rates affected the treatment group but not the control group.

Table 6 replicates these results for the years 1763 to 1830, which span the generations during which the Industrial Revolution began, spread, and accelerated. The years also span the period for which all acts are accurately dated and other statistical series pose the fewest problems. Columns (1) through (3) and (6) through (10) demonstrate that the results of Table 1 hold for this key period and for the cleanest data. Column (4) shows that these results hold when the dependent variable is limited to acts that authorized sales of strictly-settled land. Column (5) shows that these results hold when the dependent variable is limited to acts that authorized the lease of strictly-settled lands. Overall, Tables 5 and 6 indicate that changes in the interest rate coincided with changes in the number of acts authorizing the sale, lease, and reorganization of land.

Table 7 presents the results of this exercise for statutory authorities. Column (1) regresses the change in the number of statutory authority acts on the variables that influence the demand: the change in the real interest rate and the change in the level of trade. Column (2) adds to the regression variables that shift the supply curve including years of elections, changes in the prime 
minister (and thus, the coalition controlling Parliament), and the death of the monarch. Column (3) adds to the regression a vector of control variables including changes in climate (derived from tree-ring data), changes in the disease environment (as measured by the onset and end of epidemics), and changes in the real value of the land tax. Column (4) regresses the same variables for the years 1763 to 1830 , for which the dating of acts poses no problems. Column (5) regresses changes in the number of transportation acts on the full spectrum of independent variables introduced in the previous column. Column (6) regresses changes in the number of acts pertaining to urban services and infrastructure on the full spectrum of independent variables.

The results reveals a strong statistical correlation between economic conditions that influenced the value of statutory authorities and the number of statutory authorities passed by Parliament. The magnitude of the coefficients on our demand shift variables averages a little less than -1.0 for the change in the real interest rate and a little below 1.0 for the change in trade. The standard errors on those variables average about 0.30 and 0.28 respectively. The small size of the standard errors relative to the magnitudes indicates that the coefficients are measured precisely. The null hypothesis that the coefficients equal zero is rejected at the $1 \%$ significance level. This result holds for all specifications, including numerous permutations which we examined to determine the robustness of our result, but which to save space, have not included in this essay. ${ }^{12}$

How responsive was Parliament to changes in the demand for acts reorganizing rights? A few calculations reveal the answer to this inquiry. The standard deviation of the change in the

12 The regressions are robust to a wide range of alternative specifications which to save space, we have not included in this essay. Neither the signs nor the significance levels of the coefficients change when the endpoints of the analysis change by a decade or more. Regressions employing data only for the period for which we can date acts precisely (1764 to 1830) yield coefficients nearly identical to those for the full sample. The estimates are also unaffected by the inclusion of additional explanatory variables. When the change in industrial production appears as an explanatory variable, the results remain the same, and industrial production is insignificant, unless trade is excluded. In the latter case, the coefficient on industrial production becomes statistically and substantively significant and explains about as much of the variation in the dependent variable as had trade. Adding indictors for the onset and cessation of military hostilities does not alter the results. Interacting years of military conflict with the principal explanatory variables strengthens the results. 
real interest rate is 4.90 . The average of coefficient on the real interest rate in columns (1) through (3) is -1.03 . Multiplying those numbers indicates that a one standard deviation decline in the real interest rate coincided with an increase of 5.03 in the number of statutory authority acts. The standard deviation of the change in the number of statutory authority acts is 16.84 . Thus, a one standard deviation decline in interest rates explains approximately $30 \%(\sim 5.03 / 16.84)$ of a standard deviation change in the number of statutory authority acts. Similarly, the standard deviation of the change in trade is 4.66 . The average of coefficient on trade in columns (1) through (3) is 0.99 . The product of those numbers is 4.61 . Thus, a one standard deviation change in the volume of trade explains $27 \%$ of a standard deviation change in the number of statutory authority acts. In total, the two demand-shift variables in the regressions explain more than half of the variation in the number of statutory authority acts. Parliamentary accommodation of the public's demands, in other words, explains the majority of the annual fluctuation in statutory authority acts.

Columns (4) and (5) indicate that this finding holds for subcategories of statutory authorities associated with the modernization of the English economy: transportation improvements and urban expansion. Multiplying the standard deviation of the real rate with the coefficient in Column (4) and dividing by the standard deviation of transportation acts (11.9) indicates that fluctuations in the real rate explain $24 \%$ of the fluctuation in transportation acts. Similar calculations indicate that fluctuations in the real rate explain $21 \%$ of the fluctuation in acts for improving infrastructure and public services in urban communities. Fluctuations in trade explain $21 \%$ of the variation in transportation acts and $23 \%$ of the variation in urban acts.

Political variables also have substantial correlations with the number of statutory authorities passed by Parliament. The number of acts fell during election years and during years 
in which monarchs died and rebounded one year later. Together, these perturbations in the political process explain a little more than one quarter of the variation in statutory authorities.

Columns (7) and (8) examine a control group: changes in the number of government finance acts. The control group is uncorrelated with changes in interest rates and changes in the volume of trade. Adding the control group as an explanatory variable alters neither the signs nor the magnitudes of the other explanatory variables.

Table 8 examines enclosure acts. Columns (1) through (3) show the number of enclosures increased when interest rates fell. The number of enclosures fell when interest rates rose. This result reinforces the decades-old observation of the inverse correlation between interest rates and enclosures. We show that this relationship exists even after controlling for confounding variables and autocorrelation. Column (4) shows that there is no correlation between enclosure amendments and interest rates, which suggests that the variation in the number of enclosure acts was not driven by changes in unobserved factors correlated with our explanatory variables (i.e. factors that altered the costs or benefits of creating acts).

Together, Tables 5 through 8 illuminate several important patterns. First, the equilibrium number of acts reorganizing property rights changed in response to changes in the interest rate and volume of trade, two of the principal factors influencing the returns from reorganizing property rights. Proposition 1 reveals how to interpret this result. The supply curve for acts of Parliament sloped upwards, but was not vertical. The political process, in other words, responded flexibly to demands to reorganize property rights. When the public requested more acts, Parliament passed more acts. When the public requested fewer acts, Parliament passed fewer acts. Second, the equilibrium number of acts reorganizing property rights also changed in response to changes in the productivity of Parliament, as measured by factors that shifted the 
length of time that Parliament sat in session and legislators' incentives for passing local legislation. Proposition 2 reveals how to interpret this result. The demand curve for acts of Parliament sloped downwards. When economic conditions increased (or decreased) returns from reorganizing property rights, the number of acts that the public desired increased (or decreased).

In sum, as the economy evolved, the public desired to adopt property-rights arrangements that enabled them to reallocate resources towards more productive uses. Parliament accommodated those desires.

\section{Discussion}

At the opening of the eighteenth century, Parliament established a forum for reorganizing rights to land and resources. This venue enabled individuals, families, and communities to exploit opportunities that could not be accommodated by the inflexible rights regime inherited from England's past. During the next two centuries, Britain experienced agricultural and industrial revolutions. The timing suggests a connection between Parliament's revolutionary approach to property rights and the economic events that followed. Evidence from an array of sources indicates that Parliament's actions did, in fact, foster economic development.

Estate acts - particularly those authorizing the sale and lease of land - exposed land to the invisible hand. Freeing resources from the shackles of the past loosened constraints on landowners, facilitated the reallocation of physical and financial assets to new and lucrative uses, and enabled the exploitation of opportunities arising in a dynamic economy. The lowering of transaction costs enhanced efficiency and encouraged investment. The lowering of such barriers has long been considered a principal force propelling European economic progress (North, 1981). 
The benefits of estate acts extended beyond the persons and property involved. Estate acts established precedents. Knowledge of what Parliament would decide when confronted with a case helped to resolve disputes within families, to safeguard the interests of investors, to determine the distribution of rents within ongoing business arrangements, and to prevent the holding-up of new projects by those seeking an inordinate share of the profits. The development of institutions solving such problems has long been considered to be one of the principal institutional innovations underlying modern capitalist economies (Williamson, 1985).

Statutory authorities played a large role in two transcendent developments: urbanization and commercialization. In rapidly expanding urban areas, statutory authorities provided fresh water, removed garbage, aided the indigent, operated forums for dispute resolution, and financed police forces. Large numbers of people living in small areas required these services. For domestic and international commerce, statutory authorities established the high-volume, longdistance transportation network. Turnpike trusts reduced freight charges and travel times by widening, resurfacing, and maintaining thoroughfares (Bogart, 2005). Canal companies enabled coal to reach emerging manufacturing centers, such as Manchester, Liverpool, Birmingham, and Leeds. Harbor-improvement authorities increased the number and draft of ships which could dock in port, facilitating the expansion of maritime commerce.

Statutory authorities of all types played a pivotal role in the accumulation of capital. In 1810 , for example, the value of capital raised by statutory authorities for canals, rivers, turnpikes, water works, docks, and gas lighting equaled 41 million pounds, or nearly $6.5 \%$ of the total capital stock (Harris 2000, p. 195).

Enclosures have been studied by numerous scholars. Many consider enclosures a catalyst for increasing agricultural productivity (Richardson, 2001). Enclosures enabled farmers to 
introduce new crops, improve livestock, reduce overuse of common resources, and react to market opportunities. Robert Allen (1992) and Gregory Clark (1998) find these factors' impact on the productivity of arable land to be positive, but limited. Enclosure acts had additional effects. Enclosures authorized the recovery of wastelands, the drainage of fens, and the construction of irrigation channels. Enclosures also transferred agricultural land to urban and industrial uses, particularly near expanding towns and cities.

Britain's system for reorganizing property rights was unique among European nations. In other nations, the transition from medieval to modern landholding systems involved spasms of reform and rebellion. In France after 1789 and Russia after 1917, for example, revolutionaries annulled laws binding land and labor to traditional tasks; voided privileges possessed by nobles, clergy, and corporations; redistributed political power; and restructured anachronistic propertyrights regimes.

Before these revolutions, inflexible property-rights regimes prevented entrepreneurs from exploiting emerging opportunities. In France, for example, the sclerotic landholding system impeded the construction of infrastructure, such as canals, even when returns from their operation would have substantially exceeded construction costs (Rosenthal, 1992). The principal problem involved establishing rights of way. Local groups who opposed projects (or hoped for a larger share of the profits) could perpetually delay construction by repeatedly suing in slow and inefficient courts. Only after its revolution did France simplify procedures for establishing rights of way. ${ }^{13}$

Britain established procedures for establishing rights of way more than a century before France and other countries on the continent. Britain created these procedures at the same time

13 Evidence also indicates that during the eighteenth century, French cultivation continued as it had in the Middle Ages. In England, however, "agriculture entered a dynamic period of rapid and far reaching change (Sexauer 1976)." 
that Parliament established procedures for passing estate, statutory authority, and enclosure acts. Why did Parliament act at that time? The proximate answer is the Glorious Revolution of 1688, after which Britain became a constitutional monarchy, and the political system changed in fundamental ways.

Parliamentary supremacy triggered transcendent political and intellectual developments. The Bill of Rights in 1689 (and subsequent legislation) encouraged the expansion of legislative activity. Parliament began meeting on a predictable, annual schedule. Parliament began setting its own agenda. Parliament established a permanent bureaucracy and procedures for processing petitions. Streamlined procedures reduced the cost of submitting bills and increased the predictability of passage. A cadre of professional solicitors and clerks emerged to help petitions through the Parliamentary process. By the 1720s, capacity expanded to the point where the legislative process could effectively accommodate almost any demand for legislation reorganizing property rights.

The political system that solidified at that time internalized a balance of political power between landowning, mercantile, courtly, and aristocratic interests. That balance enabled individuals interested in economic development to pass acts restructuring property rights and promoting economic progress. Political stability ensured that those acts would not be overturned by the ascension of new regimes, via either violent revolution or Parliamentary election. Parliament's decisions became the law of the land.

The security of property rights was not absolute. Parliament felt free to alter rights regarding resources that could be put to more productive uses. Parliament did not, however, expropriate rights to resources without compensation. Our research indicates that individuals often received remuneration for the rights that they lost. Remuneration typically left all parties as 
well off as before. Parliament, in other words, provided security for income derived from rights to property, but not security for the rights themselves. Rights typically defined who could use a piece of property, what they could employ the property for, when they could employ the property, and who would share in the resulting benefits. These rights were pliable. These rights could be altered by common consent and political decisions. This flexibility of rights enabled society's institutional foundations to adapt to new conditions and emerging opportunities.

This notion of security differs from the type of security discussed by North and Weingast (1989), which referred to protection from arbitrary royal expropriation. ${ }^{14}$ The difference between their ideas and our ideas stems from differences in opinion over the relative importance of clauses in the British Bill of Rights. North and Weingast emphasize the Bill of Right's initial affirmative clause, which prohibited the monarch from interfering with the operations of the legislature and judiciary, and which was a direct refutation of the reign of King Charles II. This clause, however, reiterated similar clauses that appeared in the Magna Carta of 1215; in a multitude of subsequent corroborating charters, confirmation, and statutes, passed during the reigns of King Henry III through Elizabeth I; and the Petition of Right, a parliamentary declaration in 1628 of the liberties of the people, assented to by King Charles I. We emphasize clauses in the Bill of Rights that were new additions to the English constitutional lexicon. These clauses enabled Parliament to sit in session for prolonged periods each year, to determine what bills to consider during each session, and to set its own agenda. These clauses guaranteed freedom of speech within Parliament and allowed opposition politicians in exile to return home. These returnees brought with them new ideas about property and government. These changes in

14 Like many economists, we believe that security from arbitrary expropriation is a prerequisite for progress. But, like most historians of early-modern Britain, we believe that such security existed in England long before the Glorious Revolution, which reestablished a status-quo that had existed before the Stuart's attempted to impose an absolute monarchy on their united kingdoms. 
the political system enabled Parliament to contemplate complex issues concerning property rights and to establish a system that protected rights to income, which minimized opposition to the reorganization of rights, and a system that encouraged institutional adaptability, which facilitated the reallocation of resources to new and more productive uses.

The seminal studies of Ronald Coase $(1960,1974)$ illuminate the importance of Britain's adaptable property-rights regime. Coase argues that in the presence of transaction costs, attaining economic efficiency requires the proper definition and allocation of property rights. In "The Problem of Social Cost (1960)" Coase argues that nineteenth-century British common and statutory law recognized these principles, and that Britain's courts and Parliament reallocated property rights to encourage economic efficiency. In "The Lighthouse in Economics," Coase (1974) argues that in the nineteenth century, Parliament's creation of statutory authorities encouraged the provision of public goods and services. Coase illuminates his assertion with an example. Parliament assigned 'lighthouse rights' to certain plots of land. Lighthouse rights allowed anyone operating a lighthouse to collect tolls from passing vessels. The customs service collected these tolls when merchants submitted customs forms, which indicated their port of origin and arrival, and thus all of the lighthouses that they passed along the way. These new lighthouse rights superseded ancient rights enshrined guaranteeing merchants transit free from tax or toll. Our research suggests that Parliament began to operate in the way that Coase described in the early eighteenth century, following the Glorious Revolution, when Parliament gained control of government and political enlightenment reached England. ${ }^{15}$

15 Previous scholars emphasized the first half of Coase's essay, "The Problem of Social Costs (1960)," which models a world without transaction costs in which any assignment of secure property rights results in an efficient outcome. We emphasize the second section of Coase's essay, which models a world with transaction costs. In such a world, some distribution of property rights lead to efficient outcomes, while others trap people in poverty. The market alone may not alleviate this affliction. Some institution, such as Parliament, must lower transaction costs and/or reassign rights in order for efficiency to arise. 
Puzzles remain concerning the causes and consequences of the property rights revolution in Britain. One puzzle concerns redistribution. Changing property rights increased some group's incomes, but potentially lowered the incomes of others. Vested interests that could be harmed would naturally lobby against legislation. Acts reorganizing property rights, however, often passed without opposition and with the support of all concerned. Why? Parliament appears to have overcome opposition by establishing mechanisms for ensuring that all pertinent parties benefited from the legislation. Parliament, in other words, ensured that legislation contained side-payments sufficient to satisfy vested interests.

A second puzzle concerns the effort which members of Parliament put into designing and passing estate, enclosure, and statutory authority acts. Parliament spent on acts affecting specific individuals and communities as much time and energy, if not more, than Parliament did on acts concerning war, taxation, trade, and colonies. Why did Parliament devote so much effort to issues affecting localities and individuals? A possible explanation is that members of Parliament devoted themselves to passing such legislation because it increased their chances of reelection and their personal incomes. Localities supported members of Parliament who advanced local interests. Competition for seats in Parliament, therefore, may have been a key factor underlying political support for institutional adaptability.

A third puzzle concerns the connection between the property-rights revolution and an intellectual revolution occurring at that time: the Enlightenment. The essence of the Enlightenment was the notion that natural laws could be identified and harnessed for the betterment of society (Mokyr 2002, 2005a, 2005b, 2005c). The reform of parliamentary process in the early eighteenth century coincided with the rise of prominent enlightened English thinkers including John Locke. In December 1689, Locke published his magnum opus, Two Treatise of 
Government. The second treatise focused on the concepts of property and legislature. Locke wrote that property should be used industriously and rationally. Rights to property formed the foundation for civil society. These rights existed by consent of the citizenry. That consent formed the law of the land (Locke, Second Treatise on Government, Chapter V, On Property, Sections 34 and 35). Locke's concepts of property rights, civil government, and consent of the governed informed the individuals who reformed Britain's political system in the late-seventeenth and early-eighteenth century. These reforms allowed all citizens (not just the King and his appointees) to utilize forms of petitions previously employed for the reorganization of royal estates, appointments to royal offices, and the assignment of rights to aristocratic estates and chartered towns. The principal modification of the old form was the addition of clauses indicating that the acts would enhance the wealth of the realm and enable individuals and communities to prosper. These clauses provide textual evidence that Enlightenment ideals influenced estate, enclosure, and statutory authority acts.

What are the broader lessons from Britain's property rights revolution? Adaptable property-rights may be as important as secure property-rights. Both may be necessary for economic development. The pair may be sufficient to trigger modern economic growth. One way to create adaptable property-rights is to establish political procedures that generate consent for change and ensure that vested interests do not oppose development. Piecemeal actions that address specific problems facing individuals and communities may be easier to implement than widespread reforms that addresses general problems. Overtime, a piecemeal process may reveal general patterns that could serve as the foundation for nationwide reforms. The Parliamentary procedures that triggered the property-rights revolution in Britain (and which remain embedded 
within Anglo-Saxon legal systems today) may have useful applications in modern developing nations. 
Table 1: Estate and Other Private Acts, Summary Statistics

\begin{tabular}{|c|c|c|c|c|c|c|c|c|c|c|c|}
\hline & Type of Acts & \multicolumn{2}{|c|}{$\Delta$ Rights } & \multicolumn{4}{|c|}{ Series in levels } & \multicolumn{4}{|c|}{ Series in differences } \\
\hline & Estate Acts & & & & & & & & & & \\
\hline (a) & All Estates & All & Some & 22.7 & 11.1 & 0 & 66 & 0.2 & 13.0 & -55 & 65 \\
\hline (b) & Estates that authorizes sales & All & Some & 11.1 & 6.3 & 0 & 33 & 0.1 & 7.2 & -33 & 30 \\
\hline (c) & Estates that authorizes leases & All & Some & 3.3 & 2.9 & 0 & 22 & 0.4 & 3.0 & -11 & 15 \\
\hline (d) & Estates that authorizes sales or leases & All & Some & 14.5 & 7.9 & 0 & 40 & 0.1 & 8.7 & -40 & 37 \\
\hline & $\begin{array}{l}\text { Comparison Group } \\
\text { Non-Estate Private Acts }\end{array}$ & & & & & & & & & & \\
\hline (e) & Marriage & No & All & 1.6 & 2.0 & 0 & 10 & 0.1 & 2.2 & -9 & 7 \\
\hline (f) & Naturalization & No & All & 7.2 & 6.3 & 0 & 36 & 0.0 & 7.2 & -29 & 22 \\
\hline (g) & Office & No & All & 0.4 & 0.9 & 0 & 7 & 0.0 & 1.2 & -6 & 7 \\
\hline (h) & Sum (Marriage, Naturalization, Office) & No & All & 9.1 & 7.6 & 0 & 46 & 0.1 & 8.7 & -34 & 25 \\
\hline
\end{tabular}

Notes: Column (1) indicates acts that changed rights to land and resources, marked "yes" for acts that did and "no" for acts that did not. Column (2) indicates acts that altered personal rights, marked "yes" for acts that did, and "some" if the act sometimes affected personal rights. Columns (3) through (6) describe the statistical properties of the original series. Columns (7) through (10) describe the statistical properties of the series in differences, i.e. where the observation in year t-1 is subtracted from the observation in year t. Columns (3) and (7) indicate the average. Columns (4) and (8) indicate the standard deviation. Columns (5) and (9) indicate the minimum value. Columns (6) and (10) indicate the maximum value. 
Table 2: Statutory Authority and Finance Acts, Summary Statistics

\begin{tabular}{|c|c|c|c|c|c|c|c|c|c|c|c|c|c|}
\hline & & \multirow[b]{2}{*}{$\begin{array}{c}\Delta \text { Rights } \\
\text { To Land } \\
(1)\end{array}$} & \multirow[b]{2}{*}{$\begin{array}{c}\text { Provide } \\
\text { I \& S } \\
\text { (2) }\end{array}$} & \multicolumn{5}{|c|}{ Series in levels } & \multicolumn{5}{|c|}{ Series in differences } \\
\hline & & & & $\begin{array}{l}\text { Avg } \\
(3)\end{array}$ & $\begin{array}{l}\text { SD } \\
(4)\end{array}$ & $\begin{array}{l}\text { Min } \\
(5) \\
\end{array}$ & $\begin{array}{c}\text { Max } \\
(6) \\
\end{array}$ & $\begin{array}{l}\text { Stat? } \\
(7)\end{array}$ & $\begin{array}{l}\text { Avg } \\
(8) \\
\end{array}$ & $\begin{array}{l}\text { SD } \\
(9) \\
\end{array}$ & $\begin{array}{l}\text { Min } \\
(10)\end{array}$ & $\begin{array}{r}\text { Max } \\
(11) \\
\end{array}$ & $\begin{array}{l}\text { Stat? } \\
(12)\end{array}$ \\
\hline & Statutory Authority $A$ & & & & & & & & & & & & \\
\hline (a) & All & All & All & 46.1 & 42 & 0 & 187 & No & 0.9 & 15.9 & -53 & 45 & Yes \\
\hline (b) & Transportation Only & All & All & 33.7 & 29.8 & 0 & 126 & No & 0.8 & 11.3 & -37 & 32 & Yes \\
\hline (c) & Urban Only & All & All & 9 & 10.5 & 0 & 53 & Yes & 0.1 & 6.6 & -22 & 26 & Yes \\
\hline (d) & $\begin{array}{l}\text { Comparison Group } \\
\text { Finance Acts }\end{array}$ & None & Some & 22.7 & 22.3 & 0 & 94 & Yes & 0.2 & 15.8 & -87 & 54 & Yes \\
\hline
\end{tabular}

Notes: Column (1) indicates acts that changed rights to land and resources, marked "All" for acts that did and "none" for acts that did not. Column (2) indicates whether the acts authorized the provision of infrastructure or services, marked "All" for acts that did and "some" for categories in which some acts authorized infrastructure and services. Columns (3) through (7) describe the statistical properties of the original series. Columns (8) through (12) describe the statistical properties of the series in differences, i.e. where the observation in year $t-1$ is subtracted from the observation in year t. Columns (3) and (8) indicate the average. Columns (4) and (9) indicate the standard deviation. Columns (5) and (10) indicate the minimum value. Columns (6) and (11) indicate the maximum value. Columns (7) and (12) indicate whether the series is stationary, indicated "yes," or whether the series is non-stationary, indicated "no." An augmented Dickey-Fuller test is used to determine whether the series possesses a unit root. 
Table 3: Enclosure Acts and Amendments, Summary Statistics

\begin{tabular}{|c|c|c|c|c|c|c|c|c|c|c|c|c|c|}
\hline & & \multirow[b]{2}{*}{$\begin{array}{c}\Delta \text { Rights } \\
\text { To Land } \\
\text { (1) }\end{array}$} & \multirow[b]{2}{*}{$\begin{array}{c}\text { Correct } \\
\text { Error } \\
(2)\end{array}$} & \multicolumn{5}{|c|}{ Series in levels } & \multicolumn{5}{|c|}{ Series in differences } \\
\hline & & & & $\begin{array}{l}\text { Avg } \\
(3)\end{array}$ & $\begin{array}{l}\text { SD } \\
(4)\end{array}$ & $\begin{array}{l}\text { Min } \\
(5)\end{array}$ & $\begin{array}{c}\text { Max } \\
(6)\end{array}$ & $\begin{array}{l}\text { Stat? } \\
(7)\end{array}$ & $\begin{array}{l}\text { Avg } \\
(8)\end{array}$ & $\begin{array}{l}\text { SD } \\
(9)\end{array}$ & $\begin{array}{l}\text { Min } \\
(10)\end{array}$ & $\begin{array}{l}\text { Max } \\
(11)\end{array}$ & $\begin{array}{l}\text { Stat? } \\
(12)\end{array}$ \\
\hline (a) & Enclosure Acts & All & None & 27.4 & 35.7 & 0 & 135 & No & 0.6 & 12.7 & -50 & 37 & Yes \\
\hline (b) & Enclosure Amendments & Some & All & 0.2 & 0.7 & 0 & 5 & Yes & 0 & 0.7 & -3 & 5 & Yes \\
\hline
\end{tabular}

Notes: Column (1) indicates acts that changed rights to land and resources, marked "all" for acts that did and "some" for categories in which some acts changed rights to land and resources while other acts did not. Column (2) indicates whether the acts amended or corrected earlier acts changing rights to land and resources, marked "all" for acts that did and "none" for acts that did not. Columns (3) through (7) describe the statistical properties of the original series. Columns (8) through (12) describe the statistical properties of the series in differences, i.e. where the observation in year $\mathrm{t}-1$ is subtracted from the observation in year t. Columns (3) and (8) indicate the average. Columns (4) and (9) indicate the standard deviation. Columns (5) and (10) indicate the minimum value. Columns (6) and (11) indicate the maximum value. Columns (7) and (12) indicate whether the series is stationary, indicated "yes," or whether the series is non-stationary, indicated "no." An augmented Dickey-Fuller test is used to determine whether the series possesses a unit root. 
Table 4: Economic and Political Explanatory Variables, Summary Statistics

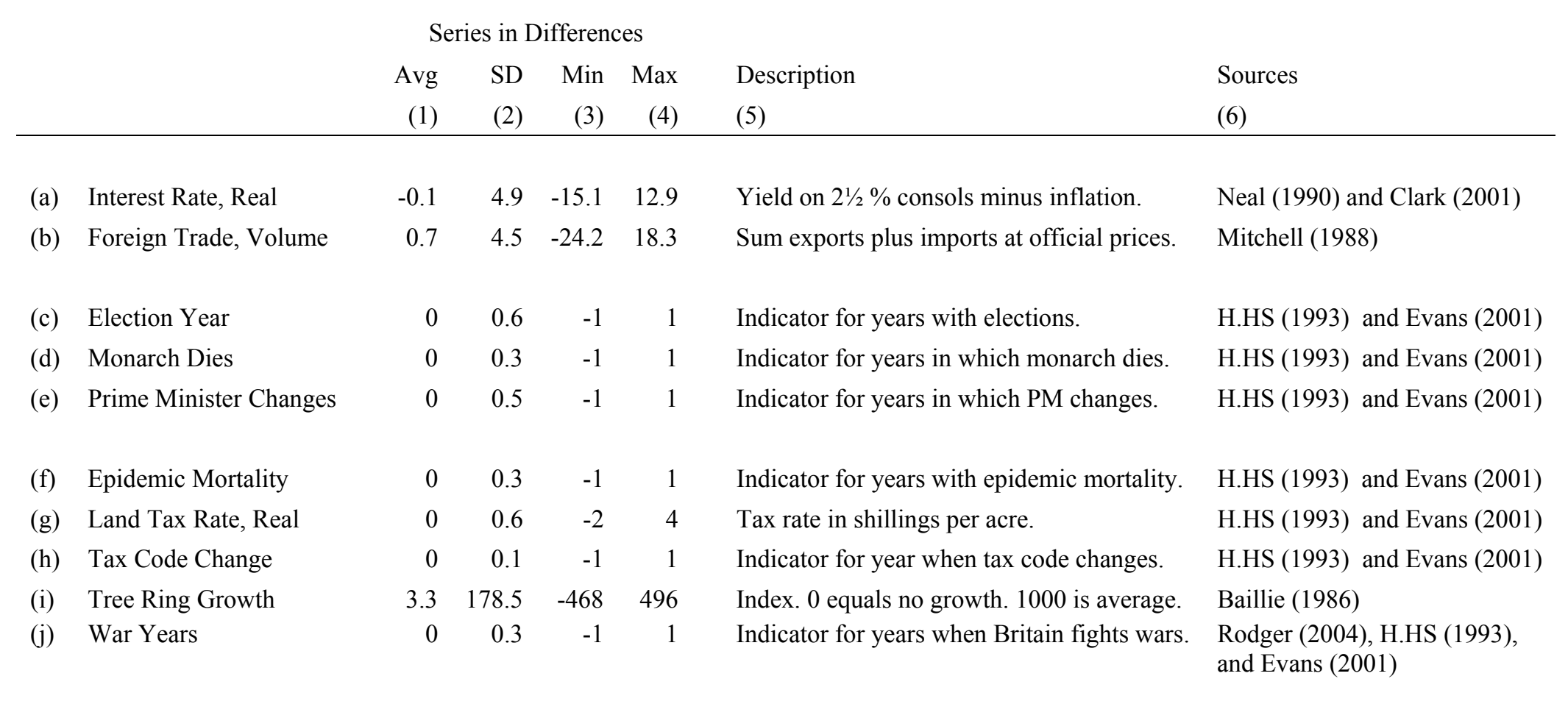

Notes: Definitions for Columns (1) through (4) identical to definitions for Columns (8) through (11) in Table 3. All of these differenced series are stationary. H.HS (1993) refers to the texts by Holmes (1993) and Holmes and Szechi (1993). 
Table 5: Estate Acts, 1705-1830, Regression Results

\begin{tabular}{|c|c|c|c|c|c|c|c|c|}
\hline \multirow[b]{2}{*}{ Variable } & \multicolumn{3}{|c|}{$\Delta$ Estate Acts } & \multicolumn{3}{|c|}{$\Delta$ Non-Estate Private Acts } & \multicolumn{2}{|c|}{$\Delta$ Estate Acts } \\
\hline & $\begin{array}{r}\text { Sales }+ \\
\text { Leases } \\
(1) \\
\end{array}$ & $\begin{array}{r}\text { Sales+ } \\
\text { Leases } \\
(2) \\
\end{array}$ & $\begin{array}{r}\text { Sales }+ \\
\text { Leases } \\
(3) \\
\end{array}$ & $\begin{array}{r}\text { Marriage } \\
(4) \\
\end{array}$ & $\begin{array}{r}\text { Naturalize } \\
(5) \\
\end{array}$ & $\begin{array}{r}\text { Office } \\
(6) \\
\end{array}$ & $\begin{array}{r}\text { Sales }+ \\
\text { Leases } \\
(7) \\
\end{array}$ & $\begin{array}{r}\text { Sales }+ \\
\text { Leases } \\
(8) \\
\end{array}$ \\
\hline$\Delta$ Real interest rate & $\begin{array}{r}\mathbf{- 0 . 2 4} \\
{[0.09]}\end{array}$ & $\begin{array}{r}\mathbf{- 0 . 2 6} \\
{[0.10]}\end{array}$ & $\begin{array}{l}\mathbf{- 0 . 2 6} \\
{[0.09}\end{array}$ & $\begin{array}{r}-0.03 \\
{[0.05]}\end{array}$ & $\begin{array}{r}-0.16 \\
{[0.18]}\end{array}$ & $\begin{array}{r}0.01 \\
{[0.01]}\end{array}$ & $\begin{array}{r}\mathbf{- 0 . 2 4} \\
{[0.10]}\end{array}$ & $\begin{array}{r}\mathbf{- 0 . 2 6} \\
{[0.10]}\end{array}$ \\
\hline$\Delta$ Trade & $\begin{array}{r}-0.07 \\
{[0.08]}\end{array}$ & $\begin{array}{r}-0.13 \\
{[0.10]}\end{array}$ & $\begin{array}{c}-0.01 \\
{[0.09]}\end{array}$ & $\begin{array}{r}0.03 \\
{[0.03]}\end{array}$ & $\begin{array}{r}0.02 \\
{[0.12]}\end{array}$ & $\begin{array}{r}0.02 \\
{[0.01]}\end{array}$ & $\begin{array}{r}-0.13 \\
{[0.09]}\end{array}$ & $\begin{array}{r}-0.13 \\
{[0.09]}\end{array}$ \\
\hline$\Delta$ Election & & $\begin{array}{r}-0.49 \\
{[1.85]}\end{array}$ & $\begin{array}{r}-0.46 \\
{[2.03]}\end{array}$ & $\begin{array}{r}-0.58 \\
{[0.44]}\end{array}$ & $\begin{array}{c}-1.01 \\
{[1.16]}\end{array}$ & $\begin{array}{r}0.06 \\
{[0.12]}\end{array}$ & $\begin{array}{r}-0.29 \\
{[2.03]}\end{array}$ & $\begin{array}{r}-0.46 \\
{[2.03]}\end{array}$ \\
\hline$\Delta$ New Prime Minister & & $\begin{array}{r}-1.09 \\
{[1.25]}\end{array}$ & $\begin{array}{r}-1.16 \\
{[1.30]}\end{array}$ & $\begin{array}{r}0.76 \\
{[0.39]}\end{array}$ & $\begin{array}{r}1.30 \\
{[1.22]}\end{array}$ & $\begin{array}{r}0.37 \\
{[0.30]}\end{array}$ & $\begin{array}{r}-1.34 \\
{[1.27]}\end{array}$ & $\begin{array}{r}-1.16 \\
{[1.34]}\end{array}$ \\
\hline$\Delta$ Monarch Dies & & $\begin{array}{r}-1.86 \\
{[2.03]}\end{array}$ & $\begin{array}{r}-1.92 \\
{[2.31]}\end{array}$ & $\begin{array}{c}-0.82 \\
{[0.46]}\end{array}$ & $\begin{array}{r}2.65 \\
{[1.90]}\end{array}$ & $\begin{array}{r}0.85 \\
{[0.55]}\end{array}$ & $\begin{array}{c}-2.01 \\
{[2.20]}\end{array}$ & $\begin{array}{r}-1.92 \\
{[2.20]}\end{array}$ \\
\hline$\Delta$ Non-Estate Private Acts & & & & & & & $\begin{array}{r}0.09 \\
{[0.07]}\end{array}$ & \\
\hline Residuals from Estimated $\Delta$ & Non-Est & Private & & & & & & $\begin{array}{r}0.09 \\
{[0.07]}\end{array}$ \\
\hline Additional Controls? & No & No & Yes & Yes & Yes & Yes & Yes & Yes \\
\hline $\begin{array}{l}\# \text { Observations } \\
\text { F-test (deg. freedom) } \\
\text { F-test statistic }\end{array}$ & $\begin{array}{r}124 \\
(2,113) \\
478 \\
\end{array}$ & $\begin{array}{r}124 \\
(5,110) \\
2114 \\
\end{array}$ & $\begin{array}{r}124 \\
(9,105) \\
372 \\
\end{array}$ & $\begin{array}{r}124 \\
(9,105) \\
44 \\
\end{array}$ & $\begin{array}{r}124 \\
(9,105) \\
21\end{array}$ & $\begin{array}{r}124 \\
(9,105) \\
518 \\
\end{array}$ & $\begin{array}{r}124 \\
(10,104) \\
859 \\
\end{array}$ & $\begin{array}{r}124 \\
(10,104) \\
341 \\
\end{array}$ \\
\hline
\end{tabular}

Bold face indicates significant at the 5\% level. Italic indicates significance at the $10 \%$ level. Standard errors calculated using the Newey-West procedure with 9 lags. 
Table 6: Estate Acts, 1765-1830, Regression Results

\begin{tabular}{|c|c|c|c|c|c|c|c|c|c|c|}
\hline \multirow[b]{2}{*}{ Variable } & \multicolumn{5}{|c|}{$\Delta$ Estate Acts } & \multicolumn{3}{|c|}{$\Delta$ Non-Estate Private Acts } & \multicolumn{2}{|c|}{$\Delta$ Estate Acts } \\
\hline & $\begin{array}{r}\text { Sales }+ \\
\text { Leases } \\
(1)\end{array}$ & $\begin{array}{r}\text { Sales }+ \\
\text { Leases } \\
(2)\end{array}$ & $\begin{array}{r}\text { Sales }+ \\
\text { Leases } \\
(3)\end{array}$ & $\begin{array}{r}\text { Sales } \\
(4) \\
\end{array}$ & $\begin{array}{r}\text { Leases } \\
(5) \\
\end{array}$ & $\begin{array}{r}\text { Marriage } \\
(6)\end{array}$ & $\begin{array}{r}\text { Naturalize } \\
(7) \\
\end{array}$ & $\begin{array}{r}\text { Office } \\
(8) \\
\end{array}$ & $\begin{array}{r}\text { Sales+ } \\
\text { Leases } \\
(9) \\
\end{array}$ & $\begin{array}{r}\text { Sales }+ \\
\text { Leases } \\
(10) \\
\end{array}$ \\
\hline$\Delta$ Real interest rate & $\begin{array}{r}\mathbf{- 0 . 3 3} \\
{[0.09]}\end{array}$ & $\begin{array}{r}\mathbf{- 0 . 3 8} \\
{[0.09]}\end{array}$ & $\begin{array}{r}\mathbf{- 0 . 3 7} \\
{[.08]}\end{array}$ & $\begin{array}{r}\mathbf{- 0 . 1 7} \\
{[0.08]}\end{array}$ & $\begin{array}{c}-0.21 \\
{[0.11]}\end{array}$ & $\begin{array}{r}-0.10 \\
{[0.08]}\end{array}$ & $\begin{array}{r}-0.29 \\
{[0.25]}\end{array}$ & $\begin{array}{r}-0.00 \\
{[0.01]}\end{array}$ & $\begin{array}{r}-\mathbf{0 . 3 7} \\
{[0.09]}\end{array}$ & $\begin{array}{r}\mathbf{- 0 . 3 8} \\
{[0.09]}\end{array}$ \\
\hline$\Delta$ Trade & $\begin{array}{r}-0.06 \\
{[0.08]}\end{array}$ & $\begin{array}{r}-0.15 \\
{[0.09]}\end{array}$ & $\begin{array}{r}-0.15 \\
{[.09]}\end{array}$ & $\begin{array}{r}-0.02 \\
{[0.08]}\end{array}$ & $\begin{array}{r}\mathbf{- 0 . 1 3} \\
{[0.05]}\end{array}$ & $\begin{array}{r}0.04 \\
{[0.04]}\end{array}$ & $\begin{array}{r}0.03 \\
{[0.12]}\end{array}$ & $\begin{array}{r}0.01 \\
{[0.01]}\end{array}$ & $\begin{array}{r}-0.16 \\
{[0.09]}\end{array}$ & $\begin{array}{c}-0.15 \\
{[0.09]}\end{array}$ \\
\hline$\Delta$ Election & & $\begin{array}{r}-2.92 \\
{[1.82]}\end{array}$ & $\begin{array}{r}-2.85 \\
{[1.91]}\end{array}$ & $\begin{array}{r}-1.89 \\
{[1.39]}\end{array}$ & $\begin{array}{r}-1.03 \\
{[0.73]}\end{array}$ & $\begin{array}{r}-0.97 \\
{[0.64]}\end{array}$ & $\begin{array}{r}-0.17 \\
{[1.94]}\end{array}$ & $\begin{array}{r}-0.10 \\
{[0.09]}\end{array}$ & $\begin{array}{r}-2.84 \\
{[1.79]}\end{array}$ & $\begin{array}{r}-2.92 \\
{[1.85]}\end{array}$ \\
\hline$\Delta$ New Prime Minister & & $\begin{array}{r}-2.27 \\
{[0.90]}\end{array}$ & $\begin{array}{r}-2.33 \\
{[1.04]}\end{array}$ & $\begin{array}{r}\mathbf{- 1 . 5 5} \\
{[0.97]}\end{array}$ & $\begin{array}{r}-0.73 \\
{[0.50]}\end{array}$ & $\begin{array}{r}-1.55 \\
{[0.56]}\end{array}$ & $\begin{array}{r}1.67 \\
{[1.80]}\end{array}$ & $\begin{array}{r}0.49 \\
{[0.32]}\end{array}$ & $\begin{array}{r}-2.38 \\
{[0.90]}\end{array}$ & $\begin{array}{r}-2.27 \\
{[0.94]}\end{array}$ \\
\hline$\Delta$ Monarch Dies & & $\begin{array}{r}3.01 \\
{[1.76]}\end{array}$ & $\begin{array}{r}3.43 \\
{[1.99]}\end{array}$ & $\begin{array}{r}3.20 \\
{[0.95]}\end{array}$ & $\begin{array}{r}-0.19 \\
{[1.13]}\end{array}$ & $\begin{array}{c}-0.32 \\
{[0.68]}\end{array}$ & $\begin{array}{r}3.99 \\
{[1.80]}\end{array}$ & $\begin{array}{r}0.27 \\
{[0.16]}\end{array}$ & $\begin{array}{r}2.87 \\
{[1.64]}\end{array}$ & $\begin{array}{r}3.01 \\
{[1.77]}\end{array}$ \\
\hline$\Delta$ Non-Estate Private Acts & & & & & & & & & $\begin{array}{r}0.03 \\
{[0.05]}\end{array}$ & \\
\hline Residuals from Estimated & $\Delta$ Non-F & state Pri & ate Acts & & & & & & & $\begin{array}{r}0.03 \\
{[0.05]}\end{array}$ \\
\hline Additional Controls? & No & No & Yes & No & No & No & No & No & No & No \\
\hline $\begin{array}{l}\text { \# Observations } \\
\text { F-test (deg. freedom) } \\
\text { F-test statistic }\end{array}$ & $\begin{array}{r}66 \\
(2,64) \\
6\end{array}$ & $\begin{array}{r}66 \\
(5,61) \\
84.15\end{array}$ & $\begin{array}{r}66 \\
(8,58) \\
8.34\end{array}$ & $\begin{array}{r}66 \\
(5,61) \\
24.2\end{array}$ & $\begin{array}{r}66 \\
(5,61) \\
24.15\end{array}$ & $\begin{array}{r}66 \\
(5,61) \\
11.28\end{array}$ & $\begin{array}{r}66 \\
(5,61) \\
0.02\end{array}$ & $\begin{array}{r}66 \\
(5,61) \\
0.71\end{array}$ & $\begin{array}{r}66 \\
(6,60) \\
21.73\end{array}$ & $\begin{array}{r}66 \\
(6,60) \\
21.73\end{array}$ \\
\hline
\end{tabular}

Bold face indicates significant at the 5\% level. Italic indicates significance at the $10 \%$ level. Standard errors calculated using the Newey-West procedure with 9 lags. 
Table 7: Statutory Authority Acts, Regression Result

\begin{tabular}{|c|c|c|c|c|c|c|c|c|}
\hline \multirow[b]{2}{*}{ Variable } & \multicolumn{7}{|c|}{$\Delta$ Statutory Authorities } & \multirow{2}{*}{$\begin{array}{r}\Delta \text { Finance } \\
(8)\end{array}$} \\
\hline & $\begin{array}{l}\text { All } \\
(1)\end{array}$ & $\begin{array}{l}\text { All } \\
(2)\end{array}$ & $\begin{array}{l}\text { All } \\
\text { (3) }\end{array}$ & $\begin{array}{l}\text { All } \\
(4) \\
\end{array}$ & $\begin{array}{r}\text { Transport } \\
\text { (5) }\end{array}$ & $\begin{array}{r}\text { Urban } \\
(6)\end{array}$ & $\begin{array}{l}\text { All } \\
(7)\end{array}$ & \\
\hline$\Delta$ Real interest rate & $\begin{array}{r}\mathbf{- 0 . 9 8 8} \\
{[0.307]}\end{array}$ & $\begin{array}{r}\mathbf{- 1 . 0 1 9} \\
{[0.295]}\end{array}$ & $\begin{array}{r}\mathbf{- 1 . 0 7 5} \\
{[0.305]}\end{array}$ & $\begin{array}{r}-\mathbf{1 . 1 3} \\
{[.56]}\end{array}$ & $\begin{array}{r}\mathbf{- 0 . 5 8 8} \\
{[0.195]}\end{array}$ & $\begin{array}{c}\mathbf{- 0 . 3 0 2} \\
{[0.139]}\end{array}$ & $\begin{array}{r}\mathbf{- 0 . 8 6 1} \\
{[0.229]}\end{array}$ & $\begin{array}{r}-0.040 \\
{[0.308]}\end{array}$ \\
\hline$\Delta$ Trade & $\begin{array}{r}\mathbf{1 . 0 1 5} \\
{[0.313]}\end{array}$ & $\begin{array}{r}\mathbf{0 . 9 9 5} \\
{[0.262]}\end{array}$ & $\begin{array}{r}\mathbf{0 . 9 5 9} \\
{[0.266]}\end{array}$ & $\begin{array}{r}\mathbf{0 . 9 6 7} \\
{[.295]}\end{array}$ & $\begin{array}{r}\mathbf{0 . 5 3 1} \\
{[0.2549}\end{array}$ & $\begin{array}{r}\mathbf{0 . 3 4 1} \\
{[0.087]}\end{array}$ & $\begin{array}{r}\mathbf{0 . 7 9 5} \\
{[0.332]}\end{array}$ & $\begin{array}{r}0.578 \\
{[0.768]}\end{array}$ \\
\hline$\Delta$ Election & & $\begin{array}{r}\mathbf{- 6 . 6 5 8} \\
{[2.457]}\end{array}$ & $\begin{array}{r}\mathbf{- 6 . 6 8 8} \\
{[2.460]}\end{array}$ & $\begin{array}{r}\mathbf{- 8 . 9 3 1} \\
{[4.328]}\end{array}$ & $\begin{array}{r}-5.323 \\
{[1.662]}\end{array}$ & $\begin{array}{r}-0.661 \\
{[1.065]}\end{array}$ & $\begin{array}{r}-5.749 \\
{[2.290]}\end{array}$ & $\begin{array}{r}-1.827 \\
{[2.370]}\end{array}$ \\
\hline$\Delta$ New Prime Minister & & $\begin{array}{r}4.476 \\
{[3.157]}\end{array}$ & $\begin{array}{r}4.305 \\
{[3.299]}\end{array}$ & $\begin{array}{r}6.880 \\
{[5.091]}\end{array}$ & $\begin{array}{r}4.303 \\
{[2.361]}\end{array}$ & $\begin{array}{r}0.550 \\
{[1.156]}\end{array}$ & $\begin{array}{r}4.728 \\
{[3.775]}\end{array}$ & $\begin{array}{r}3.229 \\
{[3.264]}\end{array}$ \\
\hline$\Delta$ Monarch Dies & & $\begin{array}{r}-5.196 \\
{[2.662]}\end{array}$ & $\begin{array}{r}-5.590 \\
{[2.679]}\end{array}$ & $\begin{array}{r}-9.871 \\
{[6.488]}\end{array}$ & $\begin{array}{r}-2.214 \\
{[1.969]}\end{array}$ & $\begin{array}{l}-2.908 \\
{[1.706]}\end{array}$ & $\begin{array}{r}\mathbf{- 6 . 1 4 5} \\
{[3.415]}\end{array}$ & $\begin{array}{r}0.026 \\
{[3.790]}\end{array}$ \\
\hline$\Delta$ Finance acts & & & & & & & $\begin{array}{r}0.173 \\
{[0.158]}\end{array}$ & \\
\hline Additional Controls? & No & No & Yes & Yes & Yes & Yes & Yes & Yes \\
\hline \# Observations & 124 & 124 & 124 & 66 & 124 & 124 & 119 & 119 \\
\hline F-test (deg freedom) & $(2,121)$ & $(5,118)$ & $(8,115)$ & $(8,58)$ & $(8,115)$ & $(8,115)$ & $(9,110)$ & $(8,110)$ \\
\hline F-test statistic & 9.23 & 5.78 & 3.67 & 22.67 & 3.73 & 4.06 & 3.62 & 0.99 \\
\hline
\end{tabular}

Bold face indicates significant at the 5\% level. Italic indicates significance at the $10 \%$ level. Standard errors calculated using the Newey-West procedure with 9 lags. 
Table 8: Enclosure Acts

\begin{tabular}{|c|c|c|c|c|}
\hline \multirow[t]{2}{*}{ Variable } & \multicolumn{3}{|c|}{$\begin{array}{c}\Delta \text { Enclosure } \\
\text { Acts }\end{array}$} & \multirow{2}{*}{$\begin{array}{r}\Delta \text { Enclosure } \\
\text { Amendments } \\
(4) \\
\end{array}$} \\
\hline & $(1)$ & $(2)$ & (3) & \\
\hline$\Delta$ Real interest rate & $\begin{array}{l}-\mathbf{0 . 9 9} \\
{[0.17]}\end{array}$ & $\begin{array}{r}-\mathbf{0 . 5 1} \\
{[0.30]}\end{array}$ & $\begin{array}{r}\mathbf{- 0 . 5 3} \\
{[0.31]}\end{array}$ & $\begin{array}{r}0.04 \\
{[0.03]}\end{array}$ \\
\hline$\Delta$ Trade & $\begin{array}{r}0.50 \\
{[0.34]}\end{array}$ & $\begin{array}{r}0.57 \\
{[0.39]}\end{array}$ & $\begin{array}{r}0.59 \\
{[0.40]}\end{array}$ & $\begin{array}{r}\mathbf{- 0 . 0 6} \\
{[0.02]}\end{array}$ \\
\hline$\Delta$ Election & & $\begin{array}{r}-5.51 \\
{[2.89]}\end{array}$ & $\begin{array}{r}-5.57 \\
{[2.95]}\end{array}$ & $\begin{array}{r}0.20 \\
{[.45]}\end{array}$ \\
\hline$\Delta$ New Prime Minister & & $\begin{array}{r}3.17 \\
{[3.55]}\end{array}$ & $\begin{array}{r}3.12 \\
{[3.60]}\end{array}$ & $\begin{array}{r}0.15 \\
{[0.24]}\end{array}$ \\
\hline$\Delta$ Land Tax Rate & & $\begin{array}{r}-12.77 \\
{[6.88]}\end{array}$ & $\begin{array}{r}-12.63 \\
{[7.02]}\end{array}$ & $\begin{array}{r}-0.45 \\
{[0.56]}\end{array}$ \\
\hline$\Delta$ Tax Code & & $\begin{array}{r}\mathbf{- 1 6 . 1 8} \\
{[4.72]}\end{array}$ & $\begin{array}{r}\mathbf{- 1 5 . 5 4} \\
{[4.97]}\end{array}$ & $\begin{array}{r}-2.06 \\
{[0.27]}\end{array}$ \\
\hline$\Delta$ Enclosure Amendments & & & $\begin{array}{r}0.31 \\
{[0.76]}\end{array}$ & \\
\hline Additional Controls? & No & Yes & Yes & Yes \\
\hline $\begin{array}{l}\text { \# Observations } \\
\text { F-test (deg freedom) } \\
\text { F-test statistic }\end{array}$ & $\begin{array}{r}66 \\
(2,64) \\
17 \\
\end{array}$ & $\begin{array}{r}66 \\
(10,56) \\
16 \\
\end{array}$ & $\begin{array}{r}66 \\
(11,55) \\
15\end{array}$ & $\begin{array}{r}66 \\
(10,56) \\
32 \\
\end{array}$ \\
\hline
\end{tabular}

Bold face indicates significant at the 5\% level. Italic indicates significance at the $10 \%$ level. Standard errors calculated using the Newey-West procedure with 9 lags. 


\section{References}

Acemoglu, Daron and James Robinson. "Unbundling Institutions," Journal of Political Economy, 113 (October 2005), pp. 949-995.

Allen, Robert. Enclosure and the Yeoman. New York, 1992.

Baillie, Michael L.. European Oak Tree Ring Series from Lockwood, Britain, 1652-1975. QUSP - ITRDB BRIT008, World Data Center for Paleoclimatology Data Contribution Series. NOAA/NCDC Paleoclimatology Program, Boulder, Colorado, USA. 1986.

Bogart, Dan. "Did Turnpike Trusts Increase Transport Investment in Eighteenth Century England," Journal of Economic History, 65 (June 2005), pp. 439-468.

---- “Turnpike Trusts and the Transport Revolution in Eighteenth Century England," Explorations in Economic History, 42 (October 2005), pp. 479-508.

Bogart, Dan and Gary Richardson. "Parliament, Property Rights, and Public Goods," Working paper, 2007.

Clark, Gregory. "The Political Foundations of Modern Economic Growth: England, 1540-1800." Journal of Interdisciplinary History, 26 (1996), pp. 563-588.

----- “Common Sense: Common Property Rights, Efficiency, and Institutional Change.” Journal of Economic History, 58 (March 1998), pp. 73-102.

---- “The Enclosure of English Common Lands, 1475-1839," Journal of Economic History, 61 (December 2001), pp. 1009-1036.

---- "Farm Wages and Living Standards in the Industrial Revolution: England, 1670-1850," Economic History Review, 54 (August 2001), pp. 477-505.

Coase, Ronald. "The Problem of Social Cost," Journal of Law and Economics, 3 (October 1960): pp. 1-44.

---- "The Lighthouse in Economics," Journal of Law and Economics, 17 (October 1974), pp. 357-76.

Crafts, N.F.R. "Determinants of the Rate of Parliamentary Enclosure," Explorations in Economic History, 14 (1977), pp. 227-249.

English B, and Saville, J. Strict Settlement: a Guide for Historians. Hull, 1983.

Evans, Eric. The Forging of the Modern State: Early Industrial Britain, 1783-1870. Longman, 2001. 
Great Britain. Statutes of the Realm, 1225 to 1713. London: Dawsons of Pall Mall, 1807.

----- Statutes at Large, 1223 to 1806. London: Mark Baskett, Robert Baskett, Henry Woodfall, and William Strahan, 1800.

Habakkuk, John. Marriage, Debt, and the Estates System. Oxford, 1994.

Harris, Ron. Industrializing English Law. Cambridge: Cambridge University Press, 2000.

Holmes, Geoffrey. The Making of a Great Power: Late Stuart and Early Georgian Britain. 1660-1722. Longman, 1993.

Holmes, Geoffrey and D. Szechi. The Age of Oligarchy: Pre-industrial Britain, 1722-83. Longman, 1993.

Hoppit, Julian. "Patterns of Parliamentary Legislation, 1660-1800." The Historical Journal, 39 (March 1996), pp. 109-131.

---- $\quad$ Failed Legislation, 1660 - 1800. London: Hambledon Press, 1997.

Innes, Joanna. "The Local Acts of a National Parliament: Parliament's Role in Sanctioning Local Action in Eighteenth-Century Britain." pp. 23-47 in Parliament and Locality, 1660-1939, edited by David Dean and Clyve Jones. Edinburgh University Press, 1998

Langford, Paul. Public Life and the Propertied Englishman. Oxford, 1991.

La Porta, Rafael, Florencio Lopez-de-Silanes, Christian Pop-Eleches, and Andrei Shleifer. "Judicial Checks and Balances." Journal of Political Economy, 112 (2004), pp. 445-470.

Locke, John. Second Treatise on Government. Chapter V, On Property, Sections 34 and 35.

Mitchell, Brian. British Historical Statistics. Cambridge, 1988.

Mokyr, Joel. Gifts of Athena: Historical Origins of the Knowledge Economy. Princeton: Princeton University Press, 2002.

---- "Mercantilism, the Enlightenment, and the Industrial Revolution." Presented tot eh Conference in Honors of Eli F. Heckscher, Stockholm, May 2003. Ronald Findlay, Rolf Henriksson, Hokan Lindgren, and Mats Lundahl (eds), Eli F. Heckscher (1879-1952): A Celebratory Symposium. Cambridge, MA: MIT Press. 2005.

----- "The Intellectual Origins of Modern Economic Growth." Journal of Economic History, Vo. 65, No. 2 (June) 2005, pp. 285-351.

----- "The Great Synergy: The European Enlightenment as a Factor in Modern Economic Growth.” Mimeo, April 2005. 
Neal, Larry. The Rise of Financial Capitalism. Cambridge: Cambridge University Press, 1990

Newey, Whitney K. and Kenneth D. West. "A simple, Positive Semi-Definite, Heteroskedasticity and Autocorrelation Consistent Covariance Matrix." Econometrica 55 (May 1987), pp. 703-708.

North, Douglass C. Structure and Change in Economic History. London: W. W. Norton and Company, 1981.

North, Douglass C. and Barry R. Weingast. "Constitutions and Commitment: The Evolution of Institutions Governing Public Choice in Seventeenth-Century England." Journal of Economic History, 49 (December 1989), pp. 803-832.

O’Brien, Patrick. "Central Government and the Economy, 1688-1815." In Floud and McCloskey, The Cambridge Economic History of Britain since 1700, I, 2nd Edition. Cambridge: Cambridge University Press, 1994.

Richardson, Gary. "The Prudent Village: Risk Pooling Institutions in Medieval English Agriculture," Journal of Economic History, Volume 65, Number 2, (June 2005), pp. 386413.

Rodger, N. A. M. The Command of the Ocean: A Naval History of Britain, 1649-1815. New York: W. W. Norton and Company, 2004.

Rosenthal, Jean-Laurent. Fruits of the Revolution: Property Rights, Litigation, and French Agriculture, 1700-1860. Cambridge: Cambridge University Press, 1992.

Sexauer, Benjamin. "English and French Agriculture in the Late Eighteenth Century." Agricultural History, Volume 50. No. 3. (July 1976), pp. 491-505.

Smith, Adam. The Wealth of Nations. Modern Library: New York, 1994.

Tate, William Edward. A Domesday of English Enclosure Acts and Awards. Reading: University of Reading, 1978.

----- The Enclosure Movement. New York: Walker, 1967.

Turner, Michael. English Parliamentary Enclosure: Its Historical Geography and Economic History. Folkestone: Dawson-Archon Books, 1980.

----- Enclosures in Britain: 1750 to 1830. London, 1984

Webb, Sidney, and Beatrice Webb. Statutory Authorities for Special Purposes, with a summary of the development of local government Structure. Hambden, 1963. 
Williamson, Oliver. The Economics Institutions of Capitalism: Firms, Markets, and Relational Contracting. New York: Macmillan Free Press, 1983.

Wordie, J. R. "The Chronology of English Enclosure, 1500-1914.” The Economic History Review, New Series, Vol. 36, No. 4, (Nov. 1983) pp. 483-505. 